\title{
Zinc Uptake and Toxicity in the Yeasts Sporobolomyces roseus and Saccharomyces cerevisiae
}

\author{
By J. L. MOWLL AND G. M. GADD* \\ Department of Biological Sciences, University of Dundee, Dundee DDI 4HN, U.K.
}

(Received 19 April 1983)

\begin{abstract}
Sporobolomyces roseus and Saccharomyces cerevisiae accumulated zinc from zinc-containing medium. Uptake was biphasic and consisted of an initial, rapid, metabolism-independent binding of zinc to cell surfaces which was followed by slower, metabolism-dependent intracellular uptake of zinc. Spor. roseus could bind approximately eight times more zinc, per unit surface area, than could $S$. cerevisiae. Metabolism-dependent zinc uptake followed Michaelis-Menten kinetics with $K_{\mathrm{m}}$ values of 0.09 and $5.00 \mathrm{mM}-\mathrm{Zn}^{2+}$ for Spor. roseus and $S$. cerevisiae, respectively; corresponding $V_{\max }$ values were 0.51 and $9.09 \mathrm{nmol}$ $\mathrm{Zn}^{2+}(\mathrm{mg} \text { dry wt })^{-1} \min ^{-1}$. Zinc uptake by viable cells was not accompanied by potassium release in either yeast, but zinc levels which affected viability in $S$. cerevisiae caused this yeast to release $\mathrm{K}^{+}$. No efflux of $\mathrm{K}^{+}$was observed for Spor. roseus despite its greater sensitivity to zinc.
\end{abstract}

\section{INTRODUCTION}

Zinc is a metal generally considered to be low in toxicity to fungi and yeasts (Somers, 1961; Ross, 1975). Neocosmospora vasinfecta and Candida albicans could grow in zinc concentrations of up to 0.1 and $0.3 \mathrm{~mm}$, respectively (Paton \& Budd, 1972; Ross, 1982), while Candida utilis accumulated high levels of intracellular zinc [up to $122 \mathrm{nmol} \mathrm{Zn}^{2+}$ (mg dry wt) $)^{-1}$ ] without any reduction of growth rate or viability (Failla \& Weinberg, 1977; Lawford et al., 1980).

Cation uptake by yeasts is typically biphasic, involving rapid, metabolism-independent binding to cell surfaces, followed by a slower phase of metabolism-dependent intracellular uptake (Rothstein et al., 1958; Rothstein, 1959; Passow \& Rothstein, 1960; Fuhrmann \& Rothstein, 1968; Ponta \& Broda, 1970; Norris \& Kelly, 1977; Failla et al., 1976; Failla \& Weinberg, 1977; Gadd \& Mowll, 1983). The uptake of metal cations by Saccharomyces cerevisiae is generally accompanied by potassium efflux which may be an integral part of the physiological mechanism for maintenance of the ionic balance or may be a symptom of membrane disruption and cell death (Passow \& Rothstein, 1960; Norris \& Kelly, 1977; Gadd \& Mowll, 1983). Although metal uptake can be related to toxicity in some organisms - resistant strains take up less metal than do sensitive strains (Chopra, 1971; Gadd \& Griffiths, 1978, 1980) - the relationship between uptake and potassium efflux is not clear, mainly because of the lack of attention paid to viability loss (Gadd \& Mowll, 1983).

The objectives of this study were to ascertain the relationship between zinc uptake, potassium efflux and viability loss in Saccharomyces cerevisiae and in Sporobolomyces roseus Kluyver et van Niel, an organism extremely sensitive to heavy metal ions (Bewley \& Campbell, 1980; Gadd, 1983).

\section{METHODS}

Organisms, media and growth conditions. Saccharomyces cerevisiae (NCYC 78) and Sporobolomyces roseus, originally obtained from Dr C. Edwards, Department of Microbiology, University of Liverpool, were used. For routine maintenance, $S$. cerevisiae was grown on MYGP medium of composition ( $\left.\mathrm{g}^{-1}\right)$ : malt extract (Lab-M), 3.0; yeast extract (Lab-M), 3.0; bacteriological peptone (Oxoid), 5·0; D-glucose, 10·0; agar (Lab-M, grade 2), 12.0. Spor. roseus was grown on the following medium $\left(\mathrm{g} \mathrm{l}^{-1}\right)$ : bacteriological peptone (Oxoid), 3.0; yeast extract (Lab- 
M), 5.0; casein hydrolysate (BDH), 5.0; D-glucose, 40.0; agar (Lab-M, grade 2), 12.0. For liquid cultures of both organisms the defined medium of Norris \& Kelly (1977) was used with added trace elements $\left(\mathrm{MnSO}_{4} .4 \mathrm{H}_{2} \mathrm{O}\right.$, $\left.0.004 \mathrm{~g}^{-1} ; \mathrm{ZnSO}_{4} .7 \mathrm{H}_{2} \mathrm{O}, 0.004 \mathrm{~g} \mathrm{l}^{-1} ; \mathrm{CuSO}_{4} .5 \mathrm{H}_{2} \mathrm{O}, 0.0004 \mathrm{~g}^{-1}\right)$. Starter cultures were prepared by loop inoculating $50 \mathrm{ml}$ culture medium which was incubated for $24 \mathrm{~h}$. These were used to inoculate experimental flasks, containing $100 \mathrm{ml}$ medium, to an initial cell density of $5 \times 10^{6} \mathrm{ml}^{-1}$. Liquid cultures were incubated at $25^{\circ} \mathrm{C}$ on an orbital shaker (100 r.p.m.).

Preparation of cell suspensions. Cells were harvested in the exponential phase of growth (1-2 $\left.\mathrm{mg} \mathrm{dry} \mathrm{wt} \mathrm{ml}^{-1}\right)$ by centrifugation ( $2000 \mathrm{~g} \times 5 \mathrm{~min}$ ), washed twice in and finally resuspended in $5 \mathrm{mM}$-PIPES buffer, $\mathrm{pH} 6 \cdot 5$, to give a dry weight of approximately $0.4 \mathrm{mg} \mathrm{ml}^{-1}$. Suspensions were incubated at $25^{\circ} \mathrm{C}$ on a magnetic stirrer for $60 \mathrm{~min}$ prior to the addition of glucose (final concentration $50 \mathrm{mM}$ ) or distilled water. After a further $60 \mathrm{~min}$, appropriate amounts of $\mathrm{ZnSO}_{4} .7 \mathrm{H}_{2} \mathrm{O}$ were added to the suspensions. Where required, the endogenous respiration inhibitor, antimycin A (Sigma) was added (final concentration $160 \mu \mathrm{M}) 30 \mathrm{~min}$ before the zinc addition.

Ion analysis. Zinc uptake was followed by the inclusion of ${ }^{65} \mathrm{Zn}$ (Amersham) in the stocks of cold $\mathrm{ZnSO}_{4} \cdot 7 \mathrm{H}_{2} \mathrm{O}$ so that on addition to cell suspensions activities of $0 \cdot 1-0 \cdot 3 \mu \mathrm{Ci} \mathrm{ml}^{-1}\left(3 \cdot 7-11 \cdot 1 \mathrm{KBq} \mathrm{ml}^{-1}\right)$ were obtained. Samples of the cell suspensions $(0.8 \mathrm{ml})$ were taken at intervals and the cells separated from the medium by microcentrifugation through $0.5 \mathrm{ml}$ of a 'dinonyl' phthalate/silicone fluid mixture $(3: 2, \mathrm{v} / \mathrm{v})$ into $0.2 \mathrm{ml}$ of a lethal solution of $40 \%(\mathrm{v} / \mathrm{v})$ perchloric acid (Werden et al., 1972). After removal of the medium, samples of the perchloric acid layer were removed and counted in scintillation fluid based on toluene and Triton X-100 $(2: 1, \mathrm{v} / \mathrm{v})$ and containing 4.0 g PPO $1^{-1}$ and $0 \cdot 1$ g POPOP $1^{-1}$, using a Packard $300 \mathrm{CD}$ scintillation counter. Potassium release was followed by periodic removal of $5 \mathrm{ml}$ samples which were centrifuged $(2000 \mathrm{~g} \times 5 \mathrm{~min})$. Pellets were washed with distilled water, recentrifuged, extracted with $6 \mathrm{M}$-nitric acid $\left(100^{\circ} \mathrm{C}, 30 \mathrm{~min}\right)$ and analysed for potassium using an EEL flame photometer.

Other methods. Viability was assessed by the conventional spread plate technique using distilled water as diluent. Dry weights were determined using tared aluminium foil cups dried to constant weight at $105^{\circ} \mathrm{C}$. Surface areas of the cell suspensions were estimated by calculation following microscopical measurement of the cells using an eyepiece graticule. Cells of Spor. roseus were assumed to be cylindrical with hemispherical ends, while cells of $S$. cerevisiae were assumed to be spherical.

Chemicals. All chemicals used were of analytical grade. 'Dinonyl' phthalate [bis (3,5,5-trimethylhexyl) phthalate] (Fluka) was obtained from Fluorochem Ltd, Glossop, Derbyshire, U.K. and Dow Corning 550 silicone fluid from Hopkin \& Williams.

\section{RESULTS}

Biphasic accumulation of zinc from zinc-containing medium occurred in both yeasts. The initial uptake was rapid and independent of glucose, antimycin A or temperature (Fig. 1) and corresponded to the binding of $\mathrm{Zn}^{2+}$ ions to sites on the cell surface. At a zinc concentration of $0.1 \mathrm{mM}$, surface binding was estimated at 28.9 and $3.8 \mathrm{nmol}(\mathrm{mg} \text { dry } \mathrm{wt})^{-1}$ for Spor. roseus and $S$. cerevisiae, respectively. When expressed in terms of surface area, corresponding values for the two organisms were 10.8 and $1.1 \mathrm{nmol} \mathrm{mm}^{-2}$ (Fig. 1). In both yeasts, initial adsorption values at a wide range of zinc concentrations $(0.01-0.5 \mathrm{~mm})$ gave a straight line when plotted according to the Freundlich equation (Freundlich, 1926) and a mass/law plot (Scatchard, 1949) of such values gave the dissociation constant $\left(K_{\mathrm{D}}\right)$ and the number $\left(Y_{\mathrm{t}}\right)$ of high affinity binding sites from the reciprocal of the steeper slope and its intercept, respectively (Fig. 2). Calculated $K_{\mathrm{D}}$ values were $4.6 \mu \mathrm{M}-\mathrm{Zn}^{2+}$ for Spor. roseus and $9.8 \mu \mathrm{M}-\mathrm{Zn}^{2+}$ for $S$. cerevisiae, the lower value of the former corresponding with the higher affinity for zinc. The $Y_{\mathrm{t}}$ values were 14.8 and $4.7 \mathrm{nmol} \mathrm{Zn}^{2+}$ (mg dry wt $)^{-1}$ for Spor. roseus and $S$. cerevisiae, respectively, again emphasizing the higher surface binding capacity for zinc of Spor. roseus.

The amounts of surface-bound zinc were subsequently exceeded by amounts of zinc taken up into the cells (Fig. 1), a process dependent on the presence of glucose. There was little second phase uptake of zinc in the presence of antimycin A or at $4{ }^{\circ} \mathrm{C}$. At a concentration of $0.1 \mathrm{~mm}, S$. cerevisiae took up considerably more zinc than Spor. roseus, initial uptake rates being 2.52 and $0.40 \mathrm{nmol}(\mathrm{mg} \text { dry wt })^{-1} \mathrm{~min}^{-1}$, respectively. This active accumulation followed MichaelisMenten kinetics in both organisms and measurement of initial uptake rates at a range of zinc concentrations (0.01-0.5 mM) gave $K_{\mathrm{m}}$ values of $0.09 \pm 0.01$ and $5.00 \pm 0.41 \mathrm{mM}-\mathrm{Zn}$ for Spor. roseus and $S$. cerevisiae, respectively; corresponding $V_{\max }$ values were $0.51 \pm 0.05$ and $9.09 \pm$ $0.85 \mathrm{nmol} \mathrm{Zn} \mathrm{(mg} \mathrm{dry} \mathrm{wt)}{ }^{-1} \mathrm{~min}^{-1}$. 

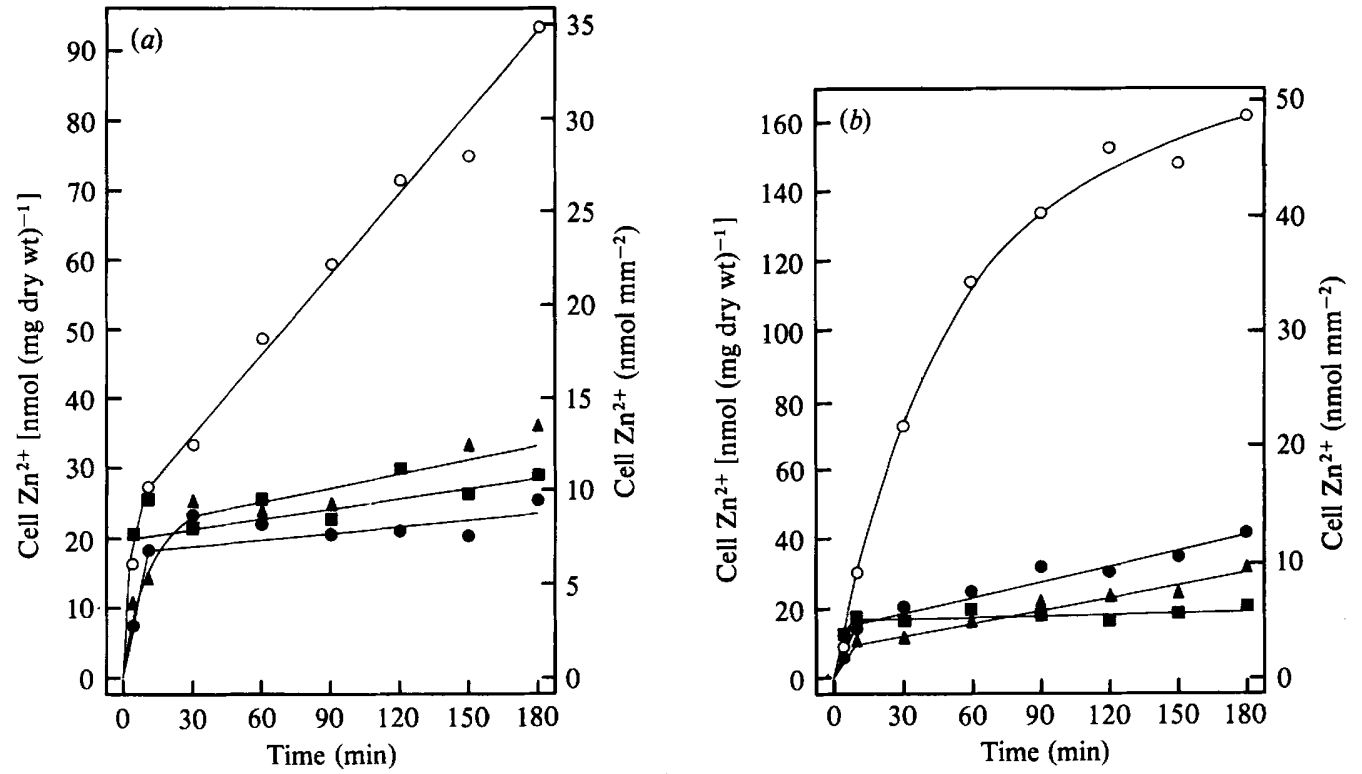

Fig. 1. $\mathrm{Zn}^{2+}$ accumulation by (a) Spor. roseus and (b) S. cerevisiae from $0.1 \mathrm{~mm}-\mathrm{ZnSO}_{4}$. At $25^{\circ} \mathrm{C}$ in the presence $(O)$ or absence $(O)$ of glucose; in the absence of glucose and the presence of $160 \mu \mathrm{M}$-antimycin

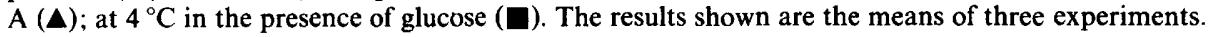

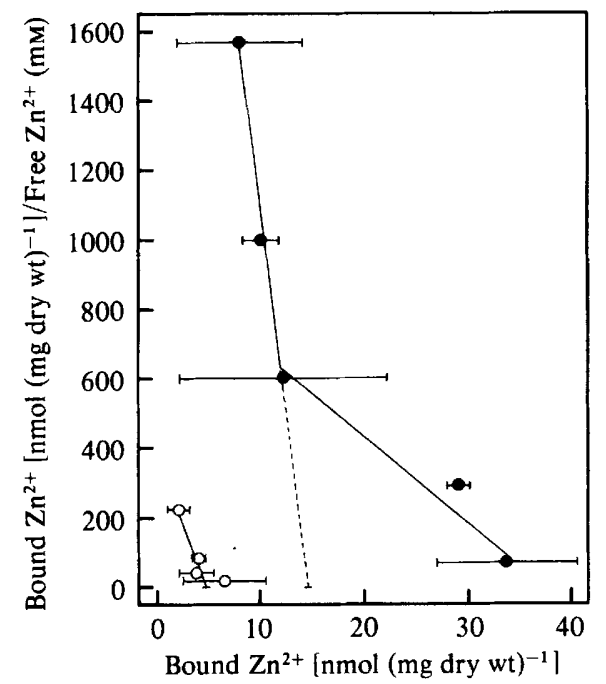

Fig. 2

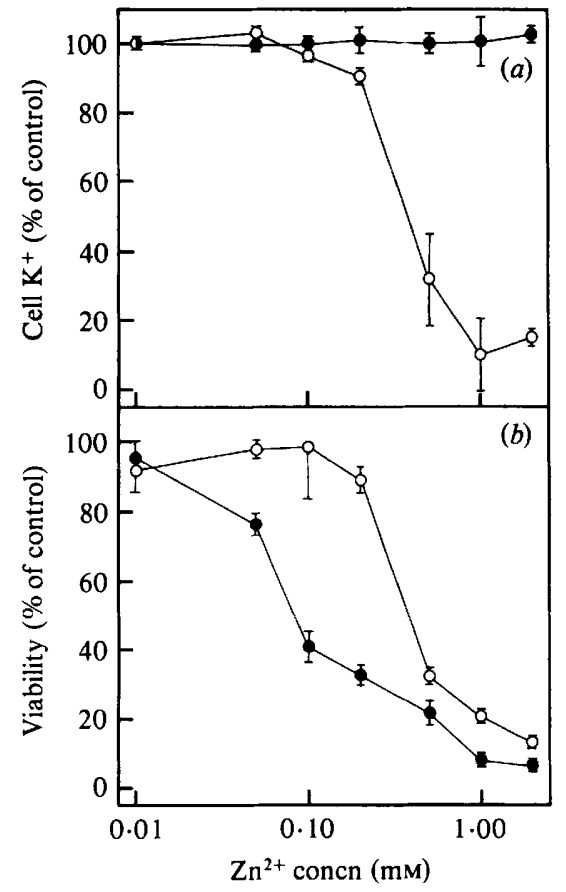

Fig. 3

Fig. 2. Mass/low plot of surface binding of $\mathrm{Zn}^{2+}$ from a range of $\mathrm{ZnSO}_{4}$ concentrations for Spor. roseus (O) and $S$. cerevisiae $(O)$. The reciprocal of the steeper slope gave the dissociation constant $\left(K_{\mathrm{D}}\right)$ while the intercept on the abscissa gave the capacity $\left(Y_{\mathrm{t}}\right)$ of the high affinity $\mathrm{Zn}^{2+}$ binding sites. Standard errors are indicated by horizontal lines through points.

Fig. 3. (a) Effect of zinc on cell $\mathrm{K}^{+}$levels in Spor. roseus (O) and $S$. cerevisiae (O). Control cell levels were 150 and $290 \mathrm{nmol} \mathrm{K}^{+}(\mathrm{mg} \text { dry wt) })^{-1}$, respectively. (b) Effect of zinc on viability of Spor. roseus $(\mathrm{O})$ and $S$. cerevisiae $(\mathrm{O})$. Cell $\mathrm{K}^{+}$and viability were measured after $3 \mathrm{~h}$ incubation and standard errors are indicated by vertical lines through points 
Accumulation of zinc by viable cells was not accompanied by any measurable extracellular release of $\mathrm{K}^{+}$ions from either organism. However, at concentrations of zinc that induced viability loss in $S$. cerevisiae ( $>0.1 \mathrm{mM}$ ), $\mathrm{K}^{+}$release was evident (Fig. 3).

Spor. roseus was much more sensitive at lower concentrations of zinc than $S$. cerevisiae and there was a general decrease in viability of the cells with increasing zinc concentrations. This was in contrast to the rapid loss of viability of $S$. cerevisiae above a threshold level of $0.1 \mathrm{~mm}$-zinc (Fig. 3). However, despite the apparent greater sensitivity of Spor. roseus to zinc, there was no measurable $\mathrm{K}^{+}$release (Fig. 3 ). In both yeasts the loss of viability was irreversible.

\section{DISCUSSION}

Differences in the surface binding capacities of each yeast were probably due to differences in cell wall structure. Crook \& Johnston (1962) found that while the walls of $S$. cerevisiae were composed of glucan and mannan with traces of chitin, the walls of Spor. roseus consisted of chitin and mannan with little glucan and, in addition, small amounts of $\gamma$-aminobutyric acid. The red pigmentation of the walls of Pyrenophora avenae removed phenyl mercuric ions from a solution of phenyl mercuric acetate (Greenaway, 1971) and it is possible that the red pigment of Spor. roseus, although different in composition to that of $P$. avenae, was similarly involved in zinc binding.

The uptake of zinc in non-lethal amounts by Spor. roseus and $S$. cerevisiae took place without any exchange of intracellular $\mathrm{K}^{+}$which contrasted with the uptake of other heavy metals by yeasts (Passow \& Rothstein, 1960; Norris \& Kelly, 1977; Gadd \& Mowll, 1983). However, many previous studies on metal uptake have not considered viability and it is often unclear whether $\mathrm{K}^{+}$release is an integral part of an uptake system or merely represents membrane disruption. In $S$. cerevisiae, while cadmium may be taken up by a glucose-dependent system at low concentrations, $\mathrm{K}^{+}$release was due to membrane damage and cell death (Gadd \& Mowll, 1983). Passow \& Rothstein (1960) suggested that the increased $\mathrm{K}^{+}$release from yeast exposed to increasing mercury levels was due to more cells showing an all-or-nothing response and there appeared to be a similar relationship in this study.

Although the relationship between zinc uptake, $\mathrm{K}^{+}$release and toxicity appeared relatively straightforward with $S$. cerevisiae, Spor. roseus exhibited several unusual features. Although much more sensitive to zinc than $S$. cerevisiae (see also Gadd, 1983), it took up considerably less zinc into the cells and there was no loss of intracellular $\mathrm{K}^{+}$despite massive viability loss. In some organisms it has been found that sensitivity to a metal is related to amounts accumulated (Chopra, 1971; Tynecka et al., 1975; Gadd \& Griffiths, 1978, 1980). The large amounts of zinc taken up by $S$. cerevisiae were indeed related to toxicity, i.e. extensive $\mathrm{K}^{+}$release and irreversible viability loss. It is clear that a different mechanism of zinc toxicity occurred in Spor. roseus. There appeared to be no membrane disruption and so the zinc may have exerted toxic action by denaturation of enzymes or other proteins within the cytoplasm.

This study illustrates the connection between zinc uptake, $\mathrm{K}^{+}$release and toxicity in $S$. cerevisiae and also shows that there is a substantially different mechanism of zinc sensitivity in Spor. roseus, uptake and toxicity occurring with no concomitant $\mathrm{K}^{+}$release.

G.M.G. gratefully acknowledges the receipt of a grant from the Natural Environment Research Council (NERC GR/3/4520).

\section{REFERENCES}

BEWLEY, R. J. F. \& CAMPBELL, R. (1980). Influence of zinc, lead and cadmium pollutants on the microflora of hawthorn leaves. Microbial Ecology 6, 227240.

CHOPRA, I. (1971). Decreased uptake of cadmium by a resistant strain of Staphylococcus aureus. Journal of General Microbiology 63, 265-267.
Crook, E. M. \& Johnston, I. R. (1962). The qualitative analysis of the cell walls of selected species of fungi. Biochemistry Journal 83, 325-331.

Failla, M. L. \& Weinberg, E. D. (1977). Cyclic accumulation of zinc by Candida utilis during growth in batch culture. Journal of General Microbiology 99 , 85-97. 
Failla, M. L., Benedict, C. D. \& Weinberg, E. D. (1976). Accumulation and storage of $\mathrm{Zn}^{2+}$ by Candida utilis. Journal of General Microbiology 94, 23-36.

Freundlich, H. (1926). Colloid and Capillary Chemistry. London: Methuen.

FuHRMANN, G. \& RothsteIn, A. (1968). The transport of $\mathrm{Zn}^{2+}, \mathrm{Co}^{2+}$ and $\mathrm{Ni}^{2+}$ into yeast cells. Biochimica et biophysica acta 163, 325-330.

GADD, G. M. (1983). The use of solid medium to study effects of cadmium, copper and zinc on yeasts and yeast-like fungi: applicability and limitations. Journal of Applied Bacteriology 54, 57-62.

GADD, G. M. \& Griffiths, A. J. (1978). Microorganisms and heavy metal toxicity. Microbial Ecology 4, 303-317.

GADD, G. M. \& Griffiths, A. J. (1980). Influence of $\mathrm{pH}$ on toxicity and uptake of copper in Aureobasidium pullulans. Transactions of the British Mycological Society 75, 91-96.

GADD, G. M. \& MowLL, J. L. (1983). The relationship between cadmium uptake, potassium release and viability in Saccharomyces cerevisiae. FEMS Microbiology Letters 16, 45-48.

GrEeNAWAY, W. (1971). Relationship between mercury resistance and pigment production in Pyrenophora avenae. Transactions of the British Mycological Society 56, 37-44.

LAWford, H. G., PIK, J. R., LaWford, G. R., Williams, T. \& Kligerman, A. (1980). Hyperaccumulation of zinc by zinc-depleted Candida utilis grown in chemostat culture. Canadian Journal of Microbiology 26, 71-76.

NorRis, P. R. \& Kelly, D. P. (1977). Accumulation of cadmium and cobalt by Saccharomyces cerevisiae. Journal of General Microbiology 99, 317-324.
Passow, H. \& Rothstein, A. (1960). The binding of mercury by the yeast cell in relation to changes in permeability. Journal of General Physiology 43, 621633.

Paton, W. H. N. \& Budd, K. (1972). Zinc uptake in Neocosmospora vasinfecta. Journal of General Microbiology 72, 173-184.

PONTA, H. \& BRODA, E. (1970). The mechanisms of uptake of zinc by baker's yeast. Planta 95, 18-26.

Ross, I. S. (1975). Some effects of heavy metals on fungal cells. Transactions of the British Mycological Society 64, 175-193.

Ross, I. S. (1982). Effect of copper, cadmium and zinc on germination and mycelial growth in Candida albicans. Transactions of the British Mycological Society 78, 543-545.

RothSTEIN, A. (1959). The cell membrane as a site of action of heavy metals. Federation Proceedings 18, 1026-1038.

Rothstein, A., Hayes, A., Jennings, D. \& Hooper, D. (1958). The active transport of $\mathbf{M g}^{2+}$ and $\mathbf{M n}^{2+}$ into the yeast cell. Journal of General Physiology 41, 585-594.

SCATCHARD, G. (1949). The attractions of proteins for small molecules and ions. Annals of the New York Academy of Sciences 51, 660-672.

Somers, E. (1961). The fungitoxicity of metal ions. Annals of Applied Biology 49, 246-253.

TYNECKA, Z., ZAJAC, J. J. \& Gos, Z. (1975). Plasmid dependent impermeability barrier to cadmium ions in Staphylococcus aureus. Acta microbiologica polonica 7, 11-20.

Werden, K., Heldt, H. W. \& Geller, G. (1972). Accumulation of bicarbonate in intact chloroplasts following a $\mathrm{pH}$ gradient. Biochimica et biophysica acta $283,430-441$. 